\title{
Leafy spurge and the species composition of a mixed-grass prairie
}

\author{
JOYCE W. BELCHER AND SCOTT D. WILSON
}

\begin{abstract}
The relationship between leafy spurge (Euphorbia esula L.) and the species composition of mixed-erass prairie was examined on both a large scale, within $a 200-\mathrm{km}^{2}$ area, and on a local scale, within a single infestation. On the large scale, cover values of 8 of the 10 most common species varied significantly $(P<0.05)$ between native prairie and spurge-dominated vegetation. Cover values of all common native species were negatively correlated with cover of leafy spurge. Within a single infestation of leafy spurge, the frequency of 5 common native species decreased significantly with leafy spurge. Most native specles were absent where leafy spurge was most abundant and species richness declined from 11 outside the infestation to 3 at the center. Ninety-five percent of leafy spurge infestations within a 374-ha area were associated with anthropogenic disturbances (vehicle tracks, road construction and fireguards) which removed nattive plant cover and exposed mineral soll. These observations corroborate experimental studies which show that leafy spurge eatablishes more readily in disturbed soil and indicate that the result of such disturbances is the replacement of native species with leafy spurge.
\end{abstract}

Key Words: effects on native grass, species richness, diversity, standing crop, disturbance

An important Eurasian invader of mixed-grass prairie is leafy spurge (Euphorbia esula L.), a perennial capable of vigorous vegetative growth and domination of large areas (Selleck et al. 1962). The biology (Selleck et al. 1962, Raju et al. 1963, Best et al. 1980, Galitz and Davis 1983), control (Bowes and Molberg 1975, Messersmith and Lym 1985), and economic impact (Messersmith and Lym 1983) of leafy spurge have been described, but the effect of leafy spurge on the species composition of native prairie has not been examined.

The major objective of this study was to describe the relationship between leafy spurge and the species composition of mixed-grass prairie. This was done at 2 levels. First, the effect of leafy spurge over a large area was determined by sampling vegetation along eight $400 \mathrm{~m}$ long transects in a $200-\mathrm{km}^{2}$ area. Second, the species composition of native prairie as a function of the abundance of leafy spurge was examined within a single infestation of leafy spurge.

Soil disturbance by humans promotes the establishment of Eurasian plant species, such as leafy spurge, in North America (Baker 1986). Best et al. (1980) showed experimentally that 45 times more seeds of leafy spurge establish on bare mineral soil than in undisturbed vegetation. Bare mineral soil appears to be a suitable seed bed, allowing leafy spurge seedlings to establish without interference from neighbors. Therefore, as a secondary objective, we examined whether spurge infestations in a native grassland were associated with soil disturbance.

\footnotetext{
Authors are research assistant, Department of Biology, University of Ottawa, Ottawa, Ontario, K1N 6N5, Canada, and postdoctoral fellow, Department of Ecology and Behavioral Biology, University of Minnesota, Minneapolis, Minn. 55455. At the time of the field work, authors were research assistant and research associate, Department of Botany, University of Manitoba, Winnipeg, Manitoba, R3T 2N2, Canada.

Research was funded by a contract from the Department of Defense awarded to $J$. Shay and by a Natural Sciences and Engineering Research Council Postdoctoral Fellowship to $\mathbf{S}$. Wilson. The authors wish to thank $\mathbf{R}$. Johnson and anonymous reviewers for helpful comments on earlier versions of this paper.

Manuscript accepted 2 August 1988.
}

\section{Study Area and Methods}

\section{Study Area}

The study was conducted in the largest remnant $\left(25 \mathrm{~km}^{2}\right)$ of mixed-grass prairie in Manitoba, Canada, located about $30 \mathrm{~km}$ SE of Brandon ( $49^{\circ} 39^{\prime} \mathrm{N}, 99^{\circ} 30^{\prime} \mathrm{W}$ ). Mixed-grass prairie is the most extensive grassland type in North America, originally covering $1.43 \times 10^{6} \mathrm{~km}^{2}, 38 \%$ of all North American grassland (Lauenroth 1979). The natural vegetation of the area is described by Bird (1927) and Coupland (1950). Native prairie is dominated by blue grama (Bouteloua gracilis [H.B.K.] Lag. ex Steud.), sedge (Carex obtusata Lilj.), porcupine grass (Stipa spartea Trin.), and little bluestem (Andropogon scoparius Michx.; nomenclature follows Scoggan 1957). In the study area, prairie is interspersed with areas dominated by Eurasian plant species, including leafy spurge, Kentucky bluegrass (Poa pratensis L.), and smooth brome (Bromus inermis Leyss.).

\section{Large-scale Effects}

The relationship between leafy spurge and native prairie species over a large area was measured at 8 sites scattered over $200 \mathbf{k m}^{2}$. Five sites were characteristic of native prairie and 3 were dominated by leafy spurge. All sites were similar in terms of soils, and topography. The native prairie sites had never been cultivated, although $\mathbf{4}$ sites had a history of occasional use for military training; the fifth was undisturbed. Two of the leafy spurge sites were previously used for intensive military training using tanks and the third had been cultivated.

A $400 \mathrm{~m}$ long transect was established at each site. Five sampling stations separated by $100-\mathrm{m}$ intervals were located along each transect. Vegetation was sampled during 1-4 Sep. 1987 in each of four $1 \times 0.5-\mathrm{m}$ quadrats placed $10 \mathrm{~m} \mathrm{~N}, \mathrm{E}, \mathrm{S}$, and $\mathrm{W}$ of each station. Cover values of plant species were recorded using Daubenmire's scale and converted to mean equivalent percent (Mueller-Dombois and Ellengberg 1974). The mean cover of each species was calculated for each transect. The covers of the 10 most abundant species were transformed (arcsine-square root) to reduce heteroscedasticity and examined with $t$-tests for significant variation between native and spurge-dominated vegetation. A correlation matrix was computed for these same species.

\section{Effects within a Single Infestation}

The relationship between leafy spurge and native prairie species was measured within a single infestation of leafy spurge centered on a vehicle trail in otherwise undisturbed native prairie. The colony was sampled during $28-31$ July 1986 by running a primary transect $25 \mathrm{~m}$ along the trail. Ten secondary transects, each $25 \mathrm{~m}$ long, ran perpendicular to the primary transect. These were placed at random $1-\mathrm{m}$ intervals along the primary transect. Five sampling stations along each secondary transect were similarly selected. In total, 50 sampling stations were examined.

A $40 \times 40-\mathrm{cm}$ quadrat, divided into a $4 \times 4-\mathrm{cm}$ grid, was placed at each sampling station. A $1.7-\mathrm{mm}$ diameter pin was dropped at 20 random points within the quadrat and all species touched by each pin were recorded. The frequency of each species was calculated as the proportion of points at which it occurred. Native species richness is the total number of native species recorded in each quadrat.

Standing crop was measured at each sampling station by clip- 

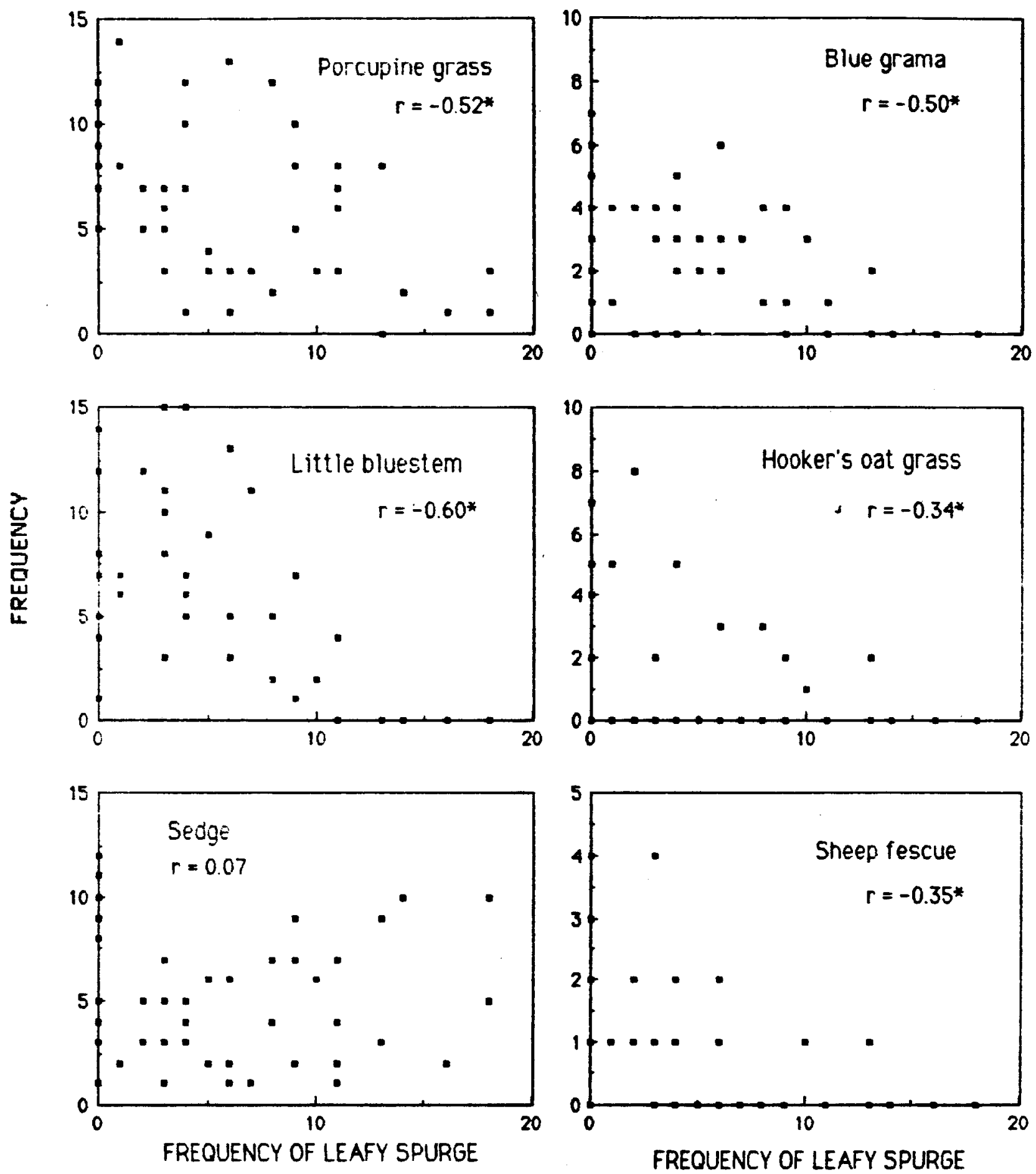

Fig. 1. Frequencies of the 6 most common native species of mixed-grass prairie as a function of the frequency of leafy spurge within a single infestation. * indicates $P<0.05$.

ping and collecting all aboveground biomass within a 20 by $20-\mathrm{cm}$ quadrat. Samples were dried to constant mass at $100^{\circ} \mathrm{C}$ and weighed. Below-ground biomass was sampled using a soil core (5 $\mathrm{cm}$ diameter, $5 \mathrm{~cm}$ deep) removed from the center of each clipped quadrat. Roots were separated from the soil by washing and sieving in a 2-mm sieve. Root samples were dried and weighed as above.

The influence of leafy spurge on community composition was tested by calculating correlations between the frequency of leafy spurge and the following variables: native species richness, species diversity $\left(\mathrm{H}^{\prime}\right)$, the frequency of 6 common species (porcupine grass, little bluestem, blue grama, Hooker's oat grass, sheep fescue, and sedge), and above and below-ground biomass.

\section{Association with Soil Disturbance}

Every infestation of leafy spurge within a 274-ha prairie bounded by roads and fireguards was visited. We noted whether the infestation was centered on a trail, road or fireguard, or tracked vehicle turn, or not associated with any disturbance. 


\section{Large-scale Effects}

Eight of the ten most common species varied significantly in cover between native prairie and vegetation dominated by leafy spurge (Table 1). The 3 most common alien species, Kentucky bluegrass, smooth brome, and leafy spurge, were not found in

Table 1. Cover values (per cent, $\bar{x} \pm$ SD) of the most abundant species in native prairie and vezetation dominated by leafy spurge. Values are means for 100 quadrats in natfve prairie and 60 quadrats in leafy spursedominated vezetation sampled in $\mathbf{a} 200 \mathrm{~km}^{2}$ area.

\begin{tabular}{llc}
\hline & Native prairie & $\begin{array}{l}\text { Vegetation dominated } \\
\text { by leafy spurge }\end{array}$ \\
\hline Native species: & & \\
Blue grama** & $31.8 \pm 15.7$ & $2.0 \pm 3.7$ \\
Sedge** & $31.4 \pm 12.7$ & $15.0 \pm 14.7$ \\
Porcupine grass*** & $30.8 \pm 11.8$ & $10.2 \pm 10.0$ \\
June grass* & $8.0 \pm 5.6$ & $4.0 \pm 5.8$ \\
Little bluestem** & $9.3 \pm 9.3$ & 0 \\
Creeping cedar & $9.1 \pm 12.5$ & $3.0 \pm 6.5$ \\
Pasture sage & $5.0 \pm 4.0$ & $4.1 \pm 3.9$ \\
Alien species: & & \\
Leafy spurge** & 0 & $33.0 \pm 24.0$ \\
Kentucky bluegrass** & 0 & $28.8 \pm 25.9$ \\
Smooth brome** & 0 & $18.8 \pm 16.5$ \\
\hline
\end{tabular}

*cover significantly different between native prairic and vegetation dominated by leafy spurge at $P<0.05 ; * *$; at $P<0.01$.

native vegetation. Most of the common native species were present in stands of leafy spurge, but in significantly lower numbers. The native grass little bluestem was not recorded in leafy spurge stands. The cover values of common native species were negatively correlated with those of common alien species in 20 out of 21 cases (Table 2), indicating replacement of native species by alien species. Species richness in native prairie (mean $=23.5$ species per transect) was significantly higher than in stands of leafy spurge (14.7) $(\mathrm{t}=7.04, P<0.01)$.

\section{Effects within a Single Infestation}

The frequencies of the 5 dominant native grasses were significantly and negatively correlated with leafy spurge; 4 species were absent where leafy spurge was most abundant (Fig. 1). Sedge showed no variation with leafy spurge frequency. Native species richness decreased significantly with increasing leafy spurge (Fig. 2). Seven to 11 species were found outside the patch but $\mathbf{4}$ species
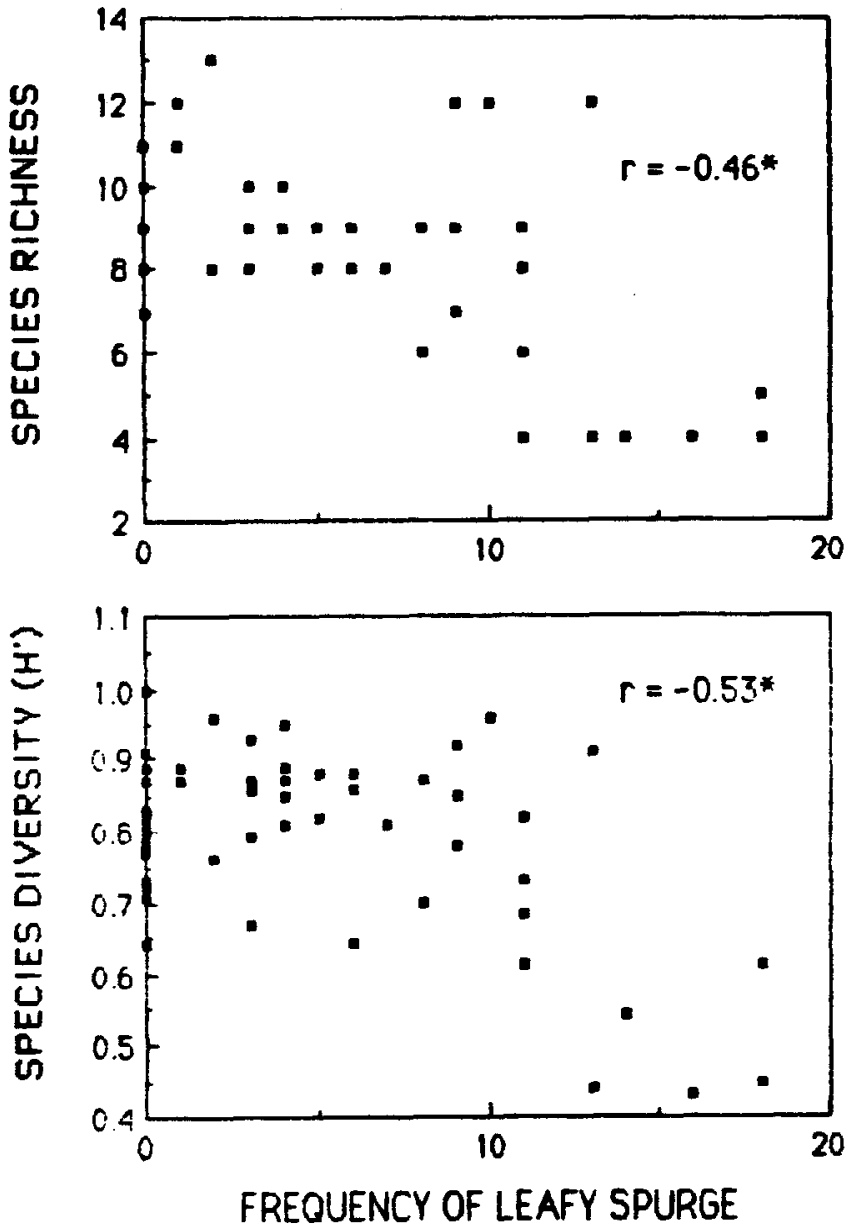

Fig. 2. Species richness and species diversity as a function of the frequency of leafy spurge within a single infestation. indicates $\mathrm{P}<0.05$.

existed where leafy spurge was most abundant. Species diversity also decreased significantly with leafy spurge (Fig. 2). Neither above- nor below-ground biomass varied significantly with frequency of leafy spurge $(r=0.13,0.04$, respectively; $P>>0.05)$, suggesting that native species were simply replaced by spurge without variation in the capacity of the soil to support phytomass.

Table 2. Correlation matrix (r values) for the 10 most abundant plant species. Values are from 160 quadrats sampled in a $200 \mathrm{~km}^{2}$ area.

\begin{tabular}{|c|c|c|c|c|c|c|c|c|c|c|}
\hline & \multicolumn{7}{|c|}{ Native species } & \multicolumn{3}{|c|}{ Alien species } \\
\hline & Blu gral & Sedge & Por gra & Jun gra & Lit blu & Cre ced & Pas sag & Lea Spu & Ken blu & Smo bro \\
\hline \multicolumn{11}{|c|}{ Native species: } \\
\hline Blu gra & 1.00 & & & & & & & & & \\
\hline Sedge & $0.54^{* * *}$ & 1.00 & & & & & & & & \\
\hline Por gra & $0.38 * *$ & $0.46^{* *}$ & 1.00 & & & & & & & \\
\hline Jun gra & 0.28 & 0.25 & 0.10 & 1.00 & & & & & & \\
\hline Lit blu & $0.38 * *$ & 0.21 & $0.62 * *$ & 0.19 & 1.00 & & & & & \\
\hline Cre ced & -0.08 & -0.14 & $0.35 *$ & 0.14 & 0.32 & 1.00 & & & & \\
\hline Pas sag & 0.11 & -0.01 & -0.08 & 0.16 & -0.09 & -0.18 & 1.00 & & & \\
\hline \multicolumn{11}{|c|}{ Alien species: } \\
\hline Lea spu & $-0.67 * *$ & $-0.48 * *$ & $-0.60^{* *}$ & $-0.46 * *$ & $-0.51^{* *}$ & -0.20 & -0.26 & 1.00 & & \\
\hline Ken blu & $-0.54 * *$ & $-0.56 * *$ & $-0.51 * *$ & $-0.33^{*}$ & $-0.48^{* * *}$ & -0.23 & 0.09 & $0.52^{* *}$ & 1.00 & \\
\hline Smo bro & $-0.64^{* * *}$ & $-0.31 *$ & $-0.54^{* *}$ & $-0.39 *$ & $-0.46^{* * *}$ & -0.08 & $-0.31^{*}$ & $0.62 * *$ & $0.43^{* *}$ & 1.00 \\
\hline
\end{tabular}

** Significant at the 0.05 and 0.01 levels respectively.

iSpecies names in full: blue grama, sedge, porcupine grass, June grass, little bluestem, creeping cedar, pasture sage, leafy spurge, Kentucky bluegrass, smooth brome. 


\section{Association with Soil Disturbance}

Eighty-three colonies of leafy spurge were found. The majority of these (49) were centered on trails, fireguards and road construction. Thirty were centered on disturbances caused by tracked vehicles turning. The remaining $\mathbf{4}$ colonies were not associated with visible soil disturbance. No colonies were associated with natural soil disturbances such as those caused by pocket gophers.

\section{Discussion and Conclusions}

Leafy spurge was clearly related to a decline in the abundance of the dominant species in native prairie, both on a large scale and within a single infestation. The only species that were significantly positively correlated with leafy spurge were the Eurasian species smooth brome and Kentucky bluegrass. This relationship might occur either because leafy spurge established in soil cultivated in preparation for the sowing of these grasses or because Eurasian agricultural species readily invade disturbed soil. Table 2 suggests that leafy spurge is one member of a community of Eurasians and that this community is associated with a decline in the cover of native prairie plants.

Leafy spurge alone can have a negative effect on native prairie, as demonstrated by the results from the sampling of a single infestation in which smooth brome and Kentucky bluegrass were not encountered (Fig. 1). The absence of 4 of the 5 common native species (little bluestem, blue grama, Hooker's oat grass, and sheep fescue) where leafy spurge was most frequent may result from shading by the relatively tall leafy spurge.

In our study area, 79 out of 83 leafy spurge infestations were centered on trails, roads, and plowed fireguards. Therefore, an important but unconsidered method of decreasing the number of infestations of leafy spurge on native prairie would be to reduce disturbances which expose mineral soil. Although disturbances at the study site resulted primarily from vehicle traffic and fireguard construction, the same principle may apply to more common disturbances such as overgrazing, road construction, and cultivation. Considerable attention has been given to chemical control of leafy spurge, but it appears that the occurrence of leafy spurge could also be reduced by limiting soil disturbances which promote its establishment.

Leafy spurge poses a considerable threat not only to the economic use of prairie for rangeland (Messersmith and Lym 1983), but also to its conservation as native vegetation.

\section{Literature Cited}

Baker, H.G. 1986. Patterns of plant invasion in North America. p. 44-57. In: Mooney, H.A. and J.A. Drake (Eds.) Ecology of biological invasions of North America and Hawaii. Springer-Verlag, Berlin.

Best, K.F., G.G. Bowes, A.G. Thomas, and M.G. Shaw. 1980. The biology of Canadian weeds. 39. Euphorbia esula L. Can. J. Plant Sci. 60:651-663.

Bird, R.D. 1927. A preliminary ecological survey of the district surrounding the entomological station at Treesbank, Manitoba. Ecology 8:207-220.

Bowes, G.G., and E.S. Molbert. 1975. Picloram for the control of leafy spurge. Can. J. Plant Sci. 55:1023-1027.

Coupland, R.T. 1950. Ecology of mixed prairie in Canada. Ecol. Monogr. 20:271-315.

Galitz, D.S., and D.G. Davis. 1983. Leafy spurge physiology and anatomy. North Dakota Farm Research. 40:20-26.

Lauenroth, W.K. 1979. Grassland primary production. North American grasslands in perspective. p. 3-24 In: N. French (Ed.) Perspectives in grassland ecology. Springer-Verlag, New York.

Messerumith, C.G., and R.G. Lym. 1983. Distribution and economics of leafy spurge in North Dakota. North Dakota Farm Res. 40:8-13.

Meseeramith, C.G., and R.G. Lym. 1985. Roller application of picloram for leafy spurge control in pastures. Weed Sci. 33:258-262.

Mueller-Dombois, D., and H. Ellenbert. 1974. Aims and methods of vegetation ecology. John Wiley, New York.

Raju, M.V.S., T.A. Steeves, and R.T. Coupland. 1963. Developmental studies on Euphorbia esula L. Morphology of the root system. Can. J. Bot. 41:579-589.

Scotean, H.J. 1957. Flora of Manitoba. National Museum of Canada. Ottawa.

Selleck, G.W., R.T. Coupland, and C. Frankton. 1962. Leafy spurge in Saskatchewan. Ecol. Monogr. 32:1-29. 